\title{
The Problematization of Fertility Treatment. Biopolitics and IVF Policy in Denmark
}

\author{
Lars Thorup Larsen
}

For citing, please use this reference to the final, published version:

Larsen, Lars Thorup (2015): "The problematization of fertility treatment: biopolitics and IVF policy in Denmark", Distinktion 16(3): 318-36.

The published version can be accessed through this link:

http://www.tandfonline.com/doi/full/10.1080/1600910X.2015.1089520

\begin{abstract}
With the demographic challenges facing many European states, one would perhaps expect the state to invoke a biopolitical imperative to 'faire vivre', as Foucault termed it, and attempt to regulate birth rates. This expectation is too simple, however, as this article shows both theoretically and empirically. In order to better understand the possible counterweights to biopolitical concerns about the birth rate, the conceptual distinction between biopolitics and governmentality is useful. Scholarly debates about biopolitics and governmentality have been surprisingly silent on what constitutes the internal relationship between the two or how they may come into conflict. The article elaborates this conceptual distinction and demonstrates its relevance in a genealogy of how fertility treatment has been problematized in Danish assisted reproduction policy. Since access to IVF treatment does not appear to follow a biopolitical imperative to 'faire vivre', it is interesting to explore and compare how IVF treatment - and its doctors, patients and children - have been problematized instead. In a variety of different ways, the biopolitical concern about the low birth rate has been overshadowed by concerns about how to govern. Either the new treatment has been problematized as an unnecessary cover for private or special interests, for instance doctors' illegitimate attemtps to self-govern, or problematization has centered on prospective parents characterized as demanding or selfish. The interface between biopolitics and fertility treatment is thus only understandable with a view to problems of governing and the resulting tension between governmentality and the biopolitical imperative to 'faire vivre'.
\end{abstract}

As do many Western European nations, Denmark faces serious demographic challenges, not only due to large generations up for retirement, but also because of low birth rates. Leading Danish fertility doctors have recently raised the problem in the public debate and called for political action to address the so-called 'national scourge of low fertility' (Ziebe et al., 2013; Sørensen et al. 2014). There are many social and environmental reasons behind the low birth rate, but despite minor fluctuations, the problem has now persisted for more than a generation and the current birth rate hovers around 1.7. 
The inability of the Danish population to reproduce itself poses interesting theoretical questions about how demographic reproduction is inscribed into the power mechanisms of modern states. If we follow the growing literature on biopolitics, it suggests that the biological reproduction of the population has become a core field of political intervention and optimization in modern states since the $18^{\text {th }}$ century. Foucault famously characterized the transformation towards biopolitics as, among other things, the introduction of a power to foster life (faire vivre, Foucault 1976: 181) as well as an imperative to optimize the life of the population. Although complex macro-developments such as demography were probably never controllable in practice, Foucault's concept of biopolitics clearly suggests that modern states would attempt to regulate its population's fertility and birth rates.

Against the theoretical backdrop of the biopolitical ambition to faire vivre, I was surprised to find that political decision-makers do not appear to address the issue of low birth rates as a target for policy intervention. There is of course no single instrument to regulate birth rates, but given that infertility is a key factor behind the low birth rate, one likely biopolitical policy response would be to expand access to assisted reproduction such as IVF treatment. The actual response has been closer to the contrary, since public funding for fertility treatment in Denmark was removed in 2010, although later restored. This raises the question how we can understand why the Danish policy on assisted reproduction seems to be disconnected from the biopolitical imperative to faire vivre.

This article aims to analyze the interface between biopolitics and fertility treatment, which is done through a genealogy of political problematizations as explained below. The purpose of doing so is to improve our understanding of what may serve to counter-balance population-centered biopolitics. This is done in two steps: The first part clarifies the conceptual distinction - and possible tension between biopolitics and governmentality followed by a brief overview of earlier studies on reproductive technologies. After a brief note on the genealogical mode of analysis and its limitations, the second part of the article analyzes the problematizations of fertility treatment as exemplified through Danish IVF policies since the technique was first introduced in the 1980s. The genealogy of problematizations of fertility treatment shows that the inability to address the problem of low birth rates is no coincidence, but a consequence of the skepticism that has surrounded the issue since the birth of IVF treatment. The second part is largely empirical, but it serves to identify possible counter-weights to biopolitical concerns about birth rates, here conceptualized through the distinction between biopolitics and governmentality.

\section{Biopolitics and Governmentality}

It is relatively rare that scholars discuss the connection between the concepts of biopolitics and governmentality. This may reflect the fact that Foucault tended to pose either one of them against discipline or sovereignty, which leaves the conceptual distinction between biopolitics and governmentality somewhat underdeveloped. It is definitely not because they originate in different contexts or remote parts of Foucault's work. Quite the contrary, since the two concepts are more or less developed simultaneously during the 1978 and 1979 lectures at the Collège de France (Foucault, 2007; 2008a; see also Lemke, 2001), although biopolitics and biopower had already been used before in Volonté de savoir (1976) and var- 
ious other texts (Foucault 1997a; 1994a). One of the reasons why only a few studies discuss both concepts is probably that they can be difficult to separate, not least because Foucault's own treatments of both concepts remain unfinished. In spite of several interconnections, it is, however, important to appreciate the conceptual difference, because it enables us to see possible tensions between biopolitical and governmental rationalities in empirical analyses.

The concepts of biopolitics and governmentality each designate a set of political rationalities whose genealogies intersect. For example, the historical emergence of the 'population' was essential in the genealogy of both. The limited parallels between the two genealogies should not, however, lead us to conflate what are also different layers of political rationality, which may or may not coincide in a given empirical context.

Biopolitics, or biopower as it is also sometimes termed, refers to political rationalities that take the life of the population as their object. Typically, these rationalities take the form of power mechanisms that intervene at the level of the population with the aim to optimize, maximize or foster life (Foucault, 1976). The regulation of the population's biological properties such as health, sickness, mortality, nutrition and of course reproduction are typical examples of these mechanisms. It is worth to add that these mechanisms are not exclusively aimed at quantitative growth, which is mainly in focus here, since Foucault also discusses how biopolitical mechanisms related to an ordering of sexuality, family life, childhood and other micro level phenomena. Agamben has tried to conceptualize biopolitics as an ontological characteristic of political communities ranging from Greek antiquity (Agamben 1998). Nevertheless, it is fair to say that biopolitics understood in Foucault's sense of the term did not exist prior to the $17^{\text {th }}$ and $18^{\text {th }}$ centuries when modern administrations began attempts to regulate and optimize the life of the population armed with knowledge forms such as statistics, demography and political economy (L.T. Larsen 2007).

Governmentality is sometimes confused with these biopolitical mechanisms, because the former perspective emerged out of Foucault's initial studies of 'security apparatuses' at the beginning of the 1978 lectures (2007, pp. 1-86). As he gets further into the longer history of the arts of government, the concept of governmentality takes on a broader field of application as a governmental rationality that goes beyond population-centered power mechanisms. First, while the main focus is on the period when the arts of government were attached to the category of the population - coinciding in broad terms with the birth of biopolitics - governmentality is not necessarily population-centered in all historical contexts. Foucault's studies of pastoral and medieval arts of government demonstrate an ambition to analyze governmentality in historical periods when the population (understood as a biological and statistical entity) did not yet exist as a scientific object. A second indication of the conceptual difference can be found in the first lecture of Foucault's 1979 course titled The Birth of Biopolitics where he explains the need to first make a digression through liberal governmentality: "[T]he analysis of biopolitics can only get under way when we have understood the general regime of governmental reason I have talked about" (Foucault 2008a: 21-22). Certain phases in the history of governmentality are thus prerequisites for the development of biopolitics; so while empirically connected, the two concepts are conceptually separate. Third, Foucault later defines governmentality in very general 
terms $(1990 ; 1994 b ; 2007,87-114 ; 2008 b)$ as 'the conduct of conduct', 'the government of self and others', or simply the 'art of governing men'. Neither of these definitions is primarily linked to the biopolitical growth of the population.

A final reason to distinguish the two concepts is to be able to use the tension between them analytically. Foucault's lectures on liberalism and neoliberalism illustrate the possible tension between the biopolitical imperative to faire vivre on one hand and the ambition to 'not govern too much' and a 'self-limitation' of governmental reason' on the other hand (2008a: 13). Self-limitation is essential to understand major welfare state reforms during the past few decades, where the role of the state in the government of society has been called into question. Other scholars have instead stressed the contemporary conflict between biopolitics and sovereignty (Ojakangas, 2005; Dean, 1999, Ch. 5), but this article aims to illustrate the tension between a biopolitical 'faire vivre' on one hand and a self-limiting governmentality on the other. This has previously been explored in the area of health promotion and the regulation of lifestyle diseases (Larsen 2010). Similar to assisted reproduction, health promotion strategies seem like obvious examples of the 'faire vivre', but are in practice counter-balanced by governmentalities - some inspired by neoliberalism - unwilling to expand public responsibility for health.

The argument here is not that the distinction between biopolitics and governmentality constitutes a grand divide in Western political reason nor is it to present the empirical analysis as 'evidence' of its veracity. The distinction is theoretical, not an empirical fact. Its function here is to make dynamic genealogies possible in which conflicting rationalities do not necessarily 'add up'. In the present case of low birth rates, the goal is to understand how political strategies tackle the challenge of low birth rates, including situations where political interventions to expand IVF access are repudiated based on a negative portrayal of the infertile.

\section{Earlier empirical studies of assisted reproduction}

Before going into the empirical case of Danish IVF policy, this section draws on existing studies on assisted reproduction to develop our vocabulary of how infertility may be problematized. Also, there is a need to specify how the Danish case deviates from the international contexts in which the earlier studies were conducted, since these are not automatically transferable. It is not the ambition here, however, to cover the broad literature on assisted reproduction (see for instance Franklin 2013; Inhorn \& Birenbaum-Carmeli 2008), in medical anthropology, STS and feminist literature, nor does the article claim to offer a new contribution here.

The feminist literature has been engaged with assisted reproduction for decades, originally focused on the medicalization of female reproduction. Thompson (2002) maps two initial stages, the first (1984-91) mostly adapting an existing feminist critique of medicine to the newly emerging techniques, and the second stage (1992-99) achieving more balanced or even ambivalent views of assisted reproduction. Later discussions of the 'new materialism' (Adrian 2006: 41; Barad 1998) departs further from the earlier techno-skepticism and embraces new modes of 'intra-action' between humans and technology. The latter is difficult to identify in Danish political discourses on fertility treatment, but the earlier feminist problematizations of reproductive technologies definitely apply to the Danish case as shown in existing studies (Bryld 2001; Petersen 2009). This includes, among 
other things, problematizations of medical doctors, lesbians, singles, the infertile or of the heteronormative values expressed in policy debates.

Existing literature also problematizes reproductive technologies with a focus on the cultural implications of reproductive technologies in medical anthropology, for instance related to fundamental social structures such as kinship (Franklin 2013; Franklin \& Roberts 2006). As much as this literature is potentially relevant to the political governing of reproduction, it is also quite remote from the problematizations that emerge in actual political debates and is largely left out here just as the legal aspects are (Jackson 2001).

Easier to integrate here are findings from the history of science concerning reproductive technologies, because they show how especially IVF treatment was seen as problematic already from its inception. As historians of science have shown (Johnson et al., 2010), Robert G. Edward's proposals for IVF research were turned down for funding several times by the Medical Research Council in the early 1970s. Neither because of the scientific content nor because it was seen as a threat to the moral status of the embryo - a common religious critique also held by the Catholic Church. Rather, IVF was problematized as being prestige research with no practical use. In a world haunted by overpopulation and in a society concerned with getting young women to postpone pregnancy with contraceptives, who could possibly see the need for a costly technique to produce more babies? (Johnson et al., 2010).

This shows that even in a country with little or no religious resistance to the idea of manipulating with nature, the dominance of secular arguments does not necessarily lead to an easy adoption of reproductive technologies. It only opens a window for other ways to conceive of fertility treatment or its beneficiaries as socially problematic, for instance presenting the techniques as being a mere cover for the interests of fame-hungry scientists or portraying infertile women as 'needy'. The case of Denmark here builds on similar experiences as the UK in that both political systems are characterized by a relative weakness of religious framings in debates about morality issues such as reproductive technologies, stem cells research, etc. (Larsen et. al 2012; Albæk et al. 2012).

\section{Problematization and genealogy}

The analysis aims to trace a genealogy of problematizations of fertility treatment, identified through political debates and discussions about IVF policy over the past 3-4 decades. The analysis is particularly interested in modes of problematization (Castel 1994). The concept of problematization has a variety of epistemological and philosophical meanings (Osborne 2003), but is used here in Foucault's sense of the term, because it is most suited to study the origin and development of political problems. Foucault introduces the term problematization briefly in the preface to L'usage des plaisirs as a type of analysis situated between analyses of individual behavior and analyses of ideologies in society (Foucault 1984: 19; Osborne 2003: 11). In an interview, Foucault connects problematization with politics by defining it as "...the development of a domain of acts, practices and thoughts that seem to me to pose problems for politics" (Foucault 1997b: 114).

Similar to how madness, crime or sexuality was shown to pose problems for politics and society in Foucault's analyses, it would be possible here to analyze how 
infertility could become a political problem in different ways. For example, it could theoretically pose a demographical problem for biopolitical goals regarding the birth rate, an economic problem related to the cost of fertility treatment, or ethical concerns about unnatural reproduction techniques. An analysis of problematization does not, however, uncover an entirely new level of reality, because discourses that problematize fertility treatment will be well known from other studies of reproductive technologies, as exemplified in the previous section's overview of feminist studies. Besides connecting these various forms of problems, the choice to analyze problematization has the advantage of not deciding beforehand that fertility treatment constitutes, for example, a generically 'ethical' problem. How it becomes perceived as a problem is an empirical question, although the theoretical literature discussed above also pays the attention to certain possibilities, such as problems of governing and problems of low birth rates.

This analysis of problematizations has several limitations. First, it is limited to policies and political discussions about the regulation of infertility (Bacchi 2012). Not in the sense of a perfectly demarcated policy question - such as whether fertility treatment should be free, for instance - because problematizations and political practices often bloom or ripple in what Foucault terms 'continuous variations' (1976: 130; see also Dean 1994: 195). The analysis is also limited to problematizations in the centralized political system, i.e. the Danish parliament 'Folketinget' and relevant ministers. ${ }^{1}$ The focus on the political system is inspired by the 'morality politics' literature (Engeli et al. 2012) from which this study also emerges. Since the initial puzzle here was how to understand the possible disconnect between fertility treatment and the biopolitical goal to 'faire vivre', it makes sense to study which type of problematization decision makers use to legitimize these policies without thereby pretending to locate any sort of 'deep origin' in political institutions.

Second, the analysis has limited ambitions regarding empirical detail by virtue of being a genealogy. Foucault distinguishes between on the one hand archeological studies of problematization with detailed content on problem forms at a given time, and on the other hand, genealogical studies that establishes the temporal modifications of practices (1984: 19). This analysis falls in the latter category, and while genealogies are by definition incomplete (Foucault, 2001; Walters, 2012, p. 16-7), the empirical scope is deliberately limited here to include only political discussions of IVF treatment and the regulation thereof - i.e. who may perform it on whom and at whose expense - since these appears to have generated the most conflict. This leaves out a few earlier documents on insemination (Justitsministeriet 1953$)^{2}$, but also a number of regulations on related policy questions such as sperm donation (Adrian 2010) or stem cells (Albæk et al. 2012).

Third, the levels of methodological transparency and documentation offered in a genealogy are somewhat limited compared with archeology or other types of qualitative research that emphasize a systematic exploration of data. The study builds on a thorough reading and ordering of IVF-related parliamentary debates within the period, major ministerial documents as well as four interviews with actors (three politicians and one interest group representative) involved in key decisions. The analysis is not structured as a transparent exploration of data, because the genealogy prioritizes what was termed the overall temporal modifications above, which also sacrifices some of minor, technical changes in IVF legis- 
lation. The genealogy is structured in three phases, one going until 1987 when IVF was formally introduced in the Danish health care sector; second, twenty years of reticent political debates about the 'best interest of the child'; and third, a stage after 2006 where assisted reproduction has become a more conventional political disagreement about private and public responsibilities. A brief introduction to each section gives an overview of the problematizations identified in the period.

\section{Doctors started 'without asking anyone'}

In the first period, the Danish political debates concerning IVF did not focus clearly on biopolitical concerns such as the birth rate, although it was at a historic low in the early 1980s. As this section aims to show, the development of fertility treatment was mainly problematized as a matter of how to govern doctors and medical technology. Danish health politics and policy was of course not only preoccupied with these issues, but had been dominated by what could be termed a 'welfarist' governmentality throughout most of the $20^{\text {th }}$ century inspired by Keynesianism and Beveridge-style universalism, although with some influences from neoliberalism since the late 1970s (Larsen \& Stone 2015). IVF policy is only very loosely related to the tension between welfarism and neoliberalism at this point, however, because the political debate concerns the medical autonomy of being allowed to perform and research on IVF, and less so about who should pay for it.

To understand the problematization in the early phase, it is instructive to recall the criticism against Edwards' research on IVF saying that it was prestige research with no practical use. A similar, but not entirely identical, skepticism resonated among Danish politicians who were not only hesitant to legislate in the area, but who also questioned the need for IVF or any other form of assisted reproduction. After the first IVF-induced birth in the UK in 1978, the early 1980s saw a growing political concerns and calls for a tighter regulation of what was often referred to in unspecific terms as 'new medical technology' (Folketinget, 1984a; 1984b). Denmark had implemented scientific ethical committees already in 197980 based on the Helsinki Declaration, but these emerged out of the medical community without significant political attention (Kappel \& Lyngeskov 2007). The area received stronger political attention in 1984 when Minister of Domestic Affairs Britta Schall Holberg (Liberal Party) set up an administrative committee to evaluate the need for further regulation, which led to a ministerial report titled 'The Price of Progress' (Fremskridtets pris, Indenrigsministeriet, 1984).

The scope of the report was initially similar to the well-known 'Warnock Report' in the UK (see Banchoff 2005). Unlike the relatively permissive recommendations of the British report, the Danish Minister urged the committee to be critical and set limits to new treatment techniques (Holberg, 2007: 29). The techno-skepticism is already apparent from the report's cover, a copperplate illustration of Adam and Eve consuming the fruit from the tree of knowledge. This is unusual in a Danish context where political arguments are almost never underlined with explicit religious references (Albæk et al. 2014). What this demonstrates is a widespread skepticism towards medical technology and autonomy across the political spectrum, but with a quite diffuse definition of medical technology. For instance, the Left Socialists proposed a parliamentary motion calling simply for a "moratorium on extended use of new medical technology" (see Folketinget, 1984a; 1984b). A 
moratorium of this sort was too radical a proposal to persuade the centre-right government, but the parliamentary debates about it show surprisingly broad consensus about the need to problematize fertility treatment and related medical technologies.

In international comparison, it is somewhat surprising how critical some of the left wing parties - especially the Socialist People's Party and its splinter party the Left Socialists - were during this period. These parties had struggled for free abortion a decade earlier and were ordinarily promoters of secular or scientific rather than religious conceptions of human life, but they nevertheless discussed IVF in very critical terms similar to early feminist critiques mentioned earlier (Thompson 2002). In most countries, the political conflict over assisted reproduction tends to follow roughly the same structure as on abortion, which is also about reproductive rights (Engeli et al. 2012; Engeli 2012). Among Danish politicians and on the left wing in particular, however, the two issues were completely separated. Whereas abortion was understood as being about women's rights, IVF and embryo research were associated with eugenics (Folketinget 1984b: 2548) and a slippery slope towards "a systematic fostering of certain human beings with specific qualities” (MP Jørgen Lenger, Left Socialists, Folketinget, 1984a: 5659).

Surprisingly, almost no legislation was passed in this early phase despite the clear calls for restrictive legislation in political debates and in the Price of Progress report. With no laws explicitly against it, doctors at Copenhagen's largest hospital, Rigshospitalet, had already initiated IVF treatment on an experimental basis (Koch \& Hansen, 2007, 13). The early Danish startup of IVF experiments around 1977-78 may help to explain why Danish politicians problematized medical autonomy so intensely at this stage. As the later Health Minister Esther Larsen (Liberal Party) write in a retrospective article, Danish fertility doctors had started offering assisted reproduction to infertile couples "without asking anyone" (E. Larsen 2007: 72).

Since there was no explicit embryo legislation, the doctors did not legally need to ask anyone and had therefore simply obtained an informed consent from the patients and approval from the committee on scientific ethics (Koch \& Hansen, 2007). By doing so, the fertility doctors had - in the eyes of the Minister and other politicians - illegitimately legislated or governed for themselves. Not only had doctors initiated IVF treatment, but the inflow of infertile patients was so large that they had also set up eligibility criteria based on factors like age, civil status and sexual orientation, most of which were later adopted into formal legislation.

The problematization of fertility treatment at this stage was thus not associated clearly with the biopolitical goal of regulating fertility or the biological reproduction of the population more broadly. Fertility treatment was only problematized indirectly, and instead seen as a problem of how to govern doctors and how to keep them from self-governing. In the few parliamentary discussions that even mentioned biopolitical aspects of reproduction, these were generally seen as problematic and compared with Nazi experiments, eugenics or Aldous Huxley's Brave New World. Most troubling to politicians, however, were not the techniques themselves as much as the underlying question of medical self-governing.

Another example of the perceived problem of medical self-governing is the establishment of the Danish Council of Ethics in 1987. To navigate the dilemma be- 
tween medical self-governing and politicians' preference for the status quo, Parliament set up this council as a debate forum (without formal authority) to counterweight medical expertise with laymen views. The council has debated many biomedical issues over the years, often with an objective to set limits to medical technology. This relatively skeptical view of medical technology is inscribed into the preamble to the law on the Council of Ethics, which says: "The council's activities should build on the premise that human life begins at the time of conception" (Indenrigsministeriet, 1987, Law 353). This is a 'prolife' position normally employed against abortion (Engeli 2012), whereas all the major Danish political parties are firmly prochoice. ${ }^{3}$

Aside from the preamble, the second restrictive aspect of the law was a complete ban on all embryo research in Denmark while the Council of Ethics prepared suggestions for new, comprehensive embryo legislation. The moratorium on embryo research also precluded research on IVF techniques, which stands in contrast to the administration of IVF treatment. Also in 1987, the National Health Board obliged the county-based health care authorities to offer IVF treatment to infertile couples under certain conditions. So, while political debates were highly critical of embryo and IVF research, IVF treatment was technically normalized on the administrative level, and without broad public attention.

In sum, fertility treatment was not problematized directly in this first period, but indirectly it was framed as being a problem of self-governing in medicine. In response to these perceived problems, the political parties mainly took a critical stance against medical authority on embryos, which was institutionalized in the Danish Council of Ethics and the simultaneous moratorium on embryo and IVF research. Few political actors at this stage, if any, associated techniques such as IVF with biopolitical reproduction as such. Little or no political attention was given to problems of infertility and low birth rates - although at a historic low - nor for that matter did any political actors express any explicit ambitions to solve or address the problems of infertile couples unable to conceive.

\section{'Fatherless Children'}

The start of the second phase is difficult to date precisely, because the 1987 moratorium put a lid on both the practice of embryo research as well as political debates about reproduction for a while. The health care sector now actually offered IVF treatment to infertile couples and thereby slowly normalized the procedure, but as this section shows, there continued to be relatively skeptical views on the issue across the political parties. The reason for characterizing this as a second period in the genealogy is thus not a move away from problematizations of fertility treatment, but that the object of problematization shifts. While a few politicians continue to see it as a problem of doctors and their professional selfinterests, most concerns center on the infertile patients who seek IVF treatment, and especially on lesbian and single women. This is more directly related to biopolitics because it concerns infertility and not simply the regulation of doctors, but still the reproduction of the population is not addressed as such. As explained below, it is rather a self-limiting governmentality that informs politicians' concerns about expanded IVF access.

The moratorium lasted until 1992 when a new law was passed based on recommendations from the Council of Ethics (Indenrigsministeriet, 1992, Law 503). The 
law mostly concerns embryo research and only indirectly IVF, since decisions about treatment were made administratively at the National Health Board. The law ended the moratorium, but only allowed embryo research projects, whose purpose was to improve fertility treatment techniques and thus not basic research on embryos. The 1992 policy process did, however, receive little political attention compared with the first dedicated law on reproductive technologies and thus IVF that was passed in 1997.

The 1997 law was the result of a very unusual policy process where the normal party-controlled procedures were dispensed in exchange for a high number of amendments and individual opinions cutting across party lines (Albæk et al. 2012). Despite a long parliamentary process, the final vote was unpredictable and almost tumultuous, since the removal of party discipline on the issue also meant that individual MPs were ill prepared to understand the high number of proposed amendments they had to vote on (Albæk, 2003).

The 1997 law mostly put the existing administrative practice into law in the sense that IVF was to be offered only to women under the age of 45 living in heterosexual relationships with no shared children. One single amendment generated the most controversy during these debates. It was not part of the Social Democratic Government's original bill, but added as amendment No. 29 saying that "Assisted reproduction can only be offered to women who are either married or live in a relationship similar to marriage" (Folketinget, 1997a). This exclusion prohibited Danish doctors from performing any reproductive technologies on lesbians and singles, irrespective of whether it was funded publicly or privately. The main reason for excluding lesbians and singles was an argument saying that it is in the 'best interest of the child' (barnets tarv) to have both a father and a mother, hence the government should not allow children to be born fatherless (see also Petersen 2009).

This problematization of fertility treatment focused on the perceived moral qualifications to become a parent, which were understood in heteronormative terms to require two parents of opposite sexes. In contrast, very little attention was given to IVF understood as disease treatment or as biopolitical intervention against low birth rates. The amendment was proposed by three social democrats who argued that the human rights of the unborn child could only be honored if Government and society protected the right to be born with both a father and a mother (Comments on amendment No. 29, Law No. 5, Folketinget, 1996-97). This was based on a memo that the Parliamentary health committee had obtained from the Danish Center for Human Rights because MPs disagreed with the initial proposal from the Government and the Council of Ethics not to require a status as a heterosexual couple. The memo does not actually conclude that state-sponsored IVF treatment on singles and lesbians would contest the UN declaration on the rights of the child, only that singles and lesbians do not have a human right to demand this treatment (Ersbøll 1996: 6). The memo also states that it constitutes a "different and rather doubtful question" whether human rights law requires the Government to exclude singles and lesbians (Ersbøll 1996: 6). The MPs behind amendment No. 29 nevertheless used the memo to conclude that the exclusion was necessary to honor the UN convention (Folketinget 1997a), which thus appears to be a misinterpretation. 
This marks a shift from the first period's problematization of fertility treatment centered on medical self-governing to a new focus on parents, their moral qualifications to be a parent and not least their alleged tendency to put their own interests above those of the unborn child. Politically speaking, however, this shift and the resulting exclusion was only made possible by a factor already present in the 1980s, namely the strong critique of IVF and medical autonomy among Danish left wing parties. These parties normally favor expansive rights for minorities and are usually critical of communitarian or heteronormative arguments about traditional family structures and the 'best interest of the child'. All the left wing parties did in fact support other policy issues advancing the rights of homosexuals, as long as the issues did not concern expansions of IVF access, for instance when the world's first registered partnership for homosexuals was introduced in 1989. One plausible interpretation of this discrepancy is that what triggered this problematization of fertility treatment was not the presence of singles or homosexuals. It was perhaps rather the perception that IVF was an unnecessary technical solution to a made-up problem, and while it was too late to avoid IVF access in general, one could question the motives of this new patient group as being either demanding or the latest objects of medicalization. This is illustrated in this speech by the Socialist People's Party spokesperson Margrethe Auken:

Instead of making childlessness into a disease that requires medical treatment based on the idea that you have a right to have a child, society's main help should be to help those people who would like a child to adopt some of the many orphans in the world who could really use some parents" (Folketinget, 1997b, 6351)

The argument echoes much of the early feminist critique of medicalization mentioned above, but it is also similar to the early British critiques of Edwards' research where assisted reproduction was characterized as a complicated technical solution that no one really needs. Further, Auken argues that assisted reproduction is not really meant to help childless parents, because it is simply a cover for doctors who would like to do as they please in the laboratory. The problematization of fertility treatment was thus still connected to doctors. It is not unusual for left wing politicians to be critical of the interests of the medical profession, but it is unusual for them to exclude citizens seeking treatment in the public health care sector and to do so with arguments about what is 'natural' and in the best interest of the child.

The following years' debate in Parliament continued the tendency of the problematization of fertility treatment to focus on lesbians (see also Bryld 2001). The debate was kept alive by a loophole in the law, which inadvertently allowed midwives to perform insemination, but not IVF, on singles and lesbians in private clinics. One particular clinic, the Stork Klinik in Copenhagen, became famous for impregnating lesbians, which the Christian Democrats tried to get outlawed in Parliament (Dahlgaard 2013; Villadsen 2002; Rasmussen 2012). The influence of the Christian Democrats on policy decisions was again negligible as these attempts to ban insemination of lesbians all failed. Indirectly, however, it may have had the political effect to shift and unite the position of all left wing parties in the opposite direction. The earlier leftist problematizations focused on doctors performing and patients seeking IVF - including singles and lesbians - almost dis- 
appeared in exchange for a unified resistance against the requirement for a heterosexual relationship.

Does the entire second period illustrate a problematization of fertility treatment orientered towards biopolitical concerns about the birth rate or a particular governmentality, then? First, no one in these debates seems to associate IVF with the problems of low birth rates at the population level. Second, the problematization is clearly aimed at the allegedly unnatural demands of patients seeking treatment rather than at the underlying problem of infertility. There appears to be a general - if perhaps implicit - view saying that IVF is an unnecessary demand brought on by doctors. Third and finally, the debate about the "best interest of the child' also reflects a self-limiting governmentality. Single mothers or children of divorced parents are not problematized in general, only in situations where patients can be portrayed as demanding a 'fatherless' child from the Government.

The critical views on 'fatherless' children illustrate a general characteristic of genealogies, which is the absence of a neutral point from where to assess the validity of each side's claims in the conflict. Opponents of the exclusion criticize the law of being discriminatory while proponents criticize lesbians and singles for demanding special treatment because their childlessness is often medically related. The political critique of medical technology is similarly entrenched between 'half full' and 'half empty' so to speak. For instance, some Danish left wing critics in the 1980s and 1990s saw their resistance as an attempt to halt the return of eugenics. Contrary to this, Koch (2004: 320-1) interprets the exclusion of lesbians and singles as the continuation of eugenics, because it denies reproductive rights to certain groups based on a view of them as being morally deficient. Whether or not the exclusion was eugenicist, IVF access was caught in a crossfire between various perceived problems of how to govern medicine and minority women portrayed as being self-interested or 'needy'. This left little room for biopolitical objectives about the 'faire vivre' of the population, because the problematization focuses almost entirely on a self-limiting governmentality and other problems associated with IVF or reproductive technologies more broadly.

\section{'Childlessness is Not a Disease'}

In the third and final period after 2006, the problematization of fertility treatment changes again, although the change is not completed until after the financial crisis as detailed below. There are a few references in the third period to the connection between IVF access and the plummeting birth rate, but still no association between fertility treatment and the biopolitical concerns about birth rates . Even more prominently than before, the political conflict about IVF is split between a left wing demanding universal access to health care versus a right wing concerned about welfare state expansion and the possible impact on individual responsibility. In this sense, it is a dispute between different governmentalities rather than biopolitical concerns that characterizes the problematization of fertility treatment in the last period as explained in the following.

The requirement for a heterosexual relationship persisted until 2006 when the rule was removed completely. This was once again the outcome of an amendment that was attached to a bill concerning other issues like egg and sperm do- 
nation and storage. The centre-right government had not proposed to remove the exclusionary rule, but it did present Parliament with a memo saying that it would probably not have damaging effects on children to be born without a father. Perhaps in an effort to hide internal disagreement within and between parties on the right wing, the government simply offered an opportunity for the opposition to remove the exclusion helped by a few Liberal Party MPs jumping the fence. Unlike in the 1990s, all left wing parties including the Social-Liberal party now stood united and removed the requirement for a heterosexual relationship. The parliamentary debates were short, but the discussion in the parliamentary Health Committee did bring back arguments about the 'best interest of the child' and allowing childbirths without a father. The debate was still turned upside down, however, because the left wing parties now stood united against their own original proposal - the exclusion of singles and lesbians - which was now deemed discriminatory.

If we seek to understand why political parties change positions and problematize fertility treatment in totally different ways over time, it is essential to see it as a political conflict (Engeli et al. 2012). The opposition towards a given policy not only indicates an ideological preference for one substantial policy over another or one type of problematization over another. It indicates a situation where the positions of left and right are co-constituted by their mutual opposition, similar to how Foucault originally argued that power nurtures its own resistance (1976: 126). When the centre-left government allowed its members and support parties to be split internally and to legislate an exclusion of lesbians and singles in 1997, the right wing opposition for the most part sat back and watched the government humiliate itself through internal disagreement. With the left wing in opposition in 2006, the tables had turned and the centre-right government was under pressure by internal disagreement whereas the entire left wing united against the exclusion. Similar to the entrenched moral conflicts in the 1990s, this tango between government and opposition leaves little room for attempts to address the biopolitical problem of low birth rates.

During the past few years, the problematization of fertility treatment has moved again towards a classic political conflict between left and right. This means a conflict about access to welfare state services and the border between private and public responsibility. Put into terms of governmentality, this is a conflict about whether or not reproduction should be governed and financed publicly, or whether it should be left to individuals and the private sector. ${ }^{4}$ Since no Danish politicians dare to challenge health care as a public responsibility in general, the only way to legitimize cutbacks on IVF treatment is to problematize whether infertility falls under what the 'welfarist' governmentality of the public health care system should reasonably be concerned with. This was done by 'de-medicalizing' the issue saying that it was not a disease and thereby an unnecessary luxury.

The discussion came up in 2010 when the centre-right government cut back public funding for IVF treatment as part of an austerity package (Regeringen 2010). This unexpected change was quite separate from other moves towards private health care in the period, since most of these involved an increase rather than a cutback of public spending on health, but with private hospitals and insurers entering the public sector (Larsen \& Stone 2015). The cutback of free IVF treatment, on the contrary, maintained the public fertility clinics but charged patients up to 
30.000 kroner (app. €4.000) annually (pre-examinations remained free). The parliamentary debate was short, because the vote was whipped by the entire government bloc and agreed upon in advance of the Parliamentary process in October 2010. Unlike the earlier chaotic parliamentary processes with free votes and many conflicting amendments, the political struggle here was entirely predictable. The left wing hammered the government for breaking the century-old universal principle of free and equal access to health care, and the government accused the opposition of fiscal irresponsibility.

Although the problematization of fertility treatment now concerned the financial aspects, the Government's line of defense also mirrored earlier forms of problematization in the sense that fertility treatment was once again problematized as a superfluous luxury similar to how cosmetic surgery is often viewed. For example, the Conservative economic spokesperson, Mike Legarth, argued in defense of the cutback: "I think we should treat disease first with the money we have; And the thing about not being able to have children, that is not a disease" (Avisen, 2010).

He thus characterized infertility as something separate from diseases and thereby attempted to maintain the principle of free and equal access to health care even with the new user payments. In the parliamentary debates, right wing politicians were less categorical about classifying infertility as a non-disease, perhaps because fertility doctors and experts had publicly argued in the meantime that the WHO actually classifies involuntary childlessness as a disease. This again led politicians to argue about the type of diseases to which infertility belongs, for example by this Conservative spokesperson: "If not being able to conceive a child is caused by a disease, it is not a disease that makes you unable to go to work and not a disease that means you cannot lead a completely normal life" (1st reading, Law No. 45, Folketinget, 2010-11).

The argument almost sounds like the Danish health care sector is only responsible for acute disease treatment, which is not the case, since it is required by law to "promote the population's health as well as prevent and treat disease, suffering and functional problems for the individual" (Law No. 913, 2010). The Health Minister Bertel Haarder (Liberal Party) tried to work his way around this by saying that since pre-examinations for fertility problems were still free, the health care system still had free access, although you would have to pay to actually get treatment before leaving (Folketinget, 2010c: 196). Since a Health Minister can hardly denounce an official WHO classification in Parliament, he instead characterized infertility as being "...a rather special type of disease where you get a lot of time to plan what you may or may not want to do with it" (Folketinget, 2010c: 196).

The debate is similar to, but also different from the negative characterizations of patients in the 1990s. Similar in the sense that IVF is characterized as a luxury and not as a solution to a medical problem. There appears to be little room for biopolitical concerns about the population's physical reproduction in any of the two periods. Also similar is that the problematization of fertility treatment focuses on patients who are characterized as being demanding and putting their own interest before those of others. The difference is that while this was previously directed at lesbians and singles, now all infertile individuals or couples are prob- 
lematized as being self-interested. A final difference is that the earlier debate was not only about funding, but also about under what circumstances IVF should even be legal.

It is important to add that there are two sides to problematizing fertility treatment through a characterization of the patients. One blaming them for being selfish and demanding, and another promoted by the opposition seeing them as victims unable to have children because of the cutback. Herein lies a discussion about whether reproduction can even be governed by economic incentives, both individually and collectively. The Health Minister Haarder (Liberal Party) argued that since it is always costly to have children, the new user payment would not affect the Danish birth rate (Folketinget 2010c: 196). The opposition argued that 30.000 kroner user payments in times of economic crisis would hurt an already low national birth rate. These arguments do to some extent address the biopolitical question of birth rates and assisted reproduction, but only limited to the specific cutback.

When a later memo from the Danish Health Ministry found that 7-800 fewer babies had been born in 2011 after the introduction of user payments, the spokesperson from the Liberal Party maintained that: "if a few thousand kroners do keep people from putting children into the world, then one should seriously consider whether having children is the right thing to do" (Politiken 2012). This problematization of patients seeking fertility treatment constitutes a perfect double bind. The patients are characterized as not having a disease, but merely a special interest in or desire for children, but they are also morally disqualified as parents if their actions turn out to be affected by economic incentives. It also shows that while there are still moral overtones lurking in the back of Danish problematizations of fertility treatment, the moral problems are no longer attached to the selfgoverning doctors. The problematization of fertility treatment addresses citizens who allegedly 'demand' a child from the government or at least help to conceive one. Most left wing politicians use a traditional defense of universal access and oppose user payments on health care whereas most right wing politicians argue that the health care sector should not try to meet every citizen's demands for IVF. Interestingly, both camps basically portray reproduction as a private issue, because the focus is on parents who would like a child, not on society's need to secure reproduction on the population level.

Fertility treatment has never been a major post in the health care budgets, but it appears to have become a preferred symbol used by right wing politicians to illustrate what they see as welfare state excess. When the centre-left government reintroduced publicly funded fertility treatment in 2012, this was criticized by the Liberal Alliance as being the epitome of the welfare state's moral decay, which was simultaneously compared with the fall of the Roman Empire (Berlingske 2011). This in unusual in Danish politics, but it illustrates how public access to fertility treatment is no longer being problematized through moral concerns about doctors or certain patient groups. Fertility treatment is now mainly characterized on the right wing as a problem for the welfare state drowning under excessive citizen demands, or by the left wing as problem of maintaining universal access to health care in a time of austerity. Even if the right wing does not challenge the welfarist governmentality on universal health insurance in general, it thus uses a neoliberal governmentality to chip off minor parts from the alleged core of disease 
treatment. Again, fertility treatment is mainly discussed as a problem of governing and as a conflict between a welfarist and a neoliberal governmentality. The biopolitical problem of the population's birth rate is not on the table.

\section{Conclusion}

The ambition of this article has been to compare various problematizations of fertility treatment and to discuss how these forms of problematization can be understood in a juxtaposition between governmentality and a biopolitical goal to 'faire vivre'. While the imperative to 'faire vivre' was not the only aspect of Foucault's conception of biopolitics, and while the 'faire vivre' may still be a prominent biopolitical objective in other contexts, it is clearly not how fertility treatment is approached in Danish health care policy. How fertility treatment is problematized in the absence of a biopolitical objective to 'faire vivre' is nevertheless interesting, because it may show which other understandings may potentially prevent the political system from addressing birth rates and reproduction in the future. There is not one way to problematize fertility treatment that dominates across this entire period, because what is seen as being problematic about fertility treatment changes. First, it was mainly the power of doctors, later it was the alleged morals of various patient groups characterized as being 'demanding', and finally it was the extension of and economic burdens on the welfare state.

If we look more closely at the problematizations of fertility treatment, the genealogy shows that while now being a fairly normal treatment in Danish society, it continues to be seen as problem in the political system. Not the same type of problem, however, but in most cases it is criticized as being more or less unnecessary and often a cover for someone else's private interests - initially those of doctors, later those of patients. While fertility treatment has never really been associated with the public's interest in birth rates, it has changed over the years whose private interest it was problematized as being a cover for, and consequently who or what needed to be governed more intensely by the political system.

First, fertility treatment was problematized as an unnecessary form of treatment and field of research, i.e. as a cover for the medical profession's interest in more patients and unlimited research freedom. It varied how strongly politicians criticized doctors and how radical solutions they imagined. Although the left wing was the most critical of medical interests, both left and right basically agreed that the practice of IVF treatment constituted a problem of governing doctors who had attempted to self-govern. The ambition to govern doctors through strict legislation and the Council of Ethics completely overshadowed the question of biopolitical reproduction as well as concerns about the patients, one could argue.

The focus on doctors persisted in the second phase after 1987, although it was now mostly patients seeking fertility treatment who became the target of problematization. Fertility treatment was already introduced in the health care sector, but politically, it continued to be characterized as somewhat superfluous. The problematization of fertility treatment now mainly centered on lesbians and single women who were allegedly demanding special treatment simply by seeking access to fertility services. Based on a questionable interpretation of human rights law, the left wing proposed a prohibition on IVF used to foster fatherless children. 
While it had a stronger moral character, this again addressed reproduction as a problem of governing citizens and balancing the needs of demanding citizens against those of (unborn) children.

Finally, when the exclusion of minorities disappeared after 2006, the problematization of fertility treatment shifted to portray all patients seeking treatment as being 'undeserving' or demanding. This involves a more predictable political conflict structure between a unified left wing advocating wide access to IVF treatment and a right wing that problematizes whether treatment should be offered publicly at all. The right wing also attempted to 'de-medicalize' infertility as a means to legitimize cutbacks on fertility treatment.

Common to this entire genealogy are at least two understandings. First, access to fertility treatment and infertility as the underlying condition are never considered to be real problems in their own right. They are generally characterized as being a cover for something else, typically the private interests of doctors or various patient groups. Second, the biopolitical reproduction of the population is never really recognized as a public problem per se in these debates. Even the left wing's advocacy of meeting patients' demands is mostly portrayed as a private right for tax-paying citizens and not as a public responsibility in itself. In other words, while access to fertility treatment is now generally open to most citizens who need it, the biopolitical problem of low birth rates remains unaddressed.

This conclusion should lead us to reconsider whether it makes sense to maintain Foucault's characterization of modern biopolitical power as involving a 'faire vivre' imperative to maximize the life of the population. Although it may still be true for other biopolitically relevant policy areas, the article calls into question whether we continue to understand the 'faire vivre' imperative as a key aspect of biopolitics since the $17^{\text {th }}$ and $18^{\text {th }}$ centuries. The main contribution is of course not conceived as some sort of 'falsification' of biopolitics. Instead, the disconnect between fertility treatment and biopolitical concerns about birth rates accentuates the need to conceptualize the forces and rationalities that serve as counterweights to biopolitics, but also to question how it makes sense to continually analyze biopolitics as the imperative to 'faire vivre'.

The Danish case suggests that the problem of reproducing the population is not conceived in terms of a biopolitical concern about the birth rate, but rather overshadowed by or reframed into problems of governmentality. Whether it is doctors, patients or sexual minorities whose behavior needs to be governed in a certain way according to political discourse, fertility treatment is associated with problems of governing rather than biopolitical concerns about the population's reproduction. This finally brings us back to the distinction between biopolitics and governmentality, because the counterweight to biopolitical concerns is typically some form of governmental rationality that questions the expansion of the state's responsibilities. Although there is of course no one governmentality standing opposed to biopolitics as such, the article has employed the conceptual distinction to separate different ways to problematize issues in political discourse. It does not mean that the broader social and cultural meaning of fertility treatment can be reduced to this distinction, far from it. The contribution of this study to the broader literature on reproductive technologies is rather to argue that political discourses on reproduction should be studied as such, i.e. we should not expect the political 
conflicts to simply reflect the broader cultural significance attached to reproductive technologies in society. As the analysis shows, political conflicts may be quite disconnected from how fertility treatment is used and understood in society at large, even if political discourses of course also sometimes reproduce external discourses such as the critique of medicalization.

\section{References}

Adrian, S. (2006). Nye skabelsesberetninger om æg, sæd og embryoner. Linköping: Linköping Universitet.

Adrian, S. W. (2010). Sperm stories: Policies and practices of sperm banking in Denmark and Sweden, European Journal of Women's Studies 17(4): 393-411.

Agamben, G. (1998). Homo Sacer: Sovereign Power and Bare Life. Stanford, CA: Stanford University Press.

Albæk, E. (2003). Political Ethics and Public Policy: Homosexuals between Moral Dilemmas and Political Considerations in Danish Parliamentary Debates, Scandinavian Political Studies 26(3): 245-67.

Albæk, E., Green-Pedersen, C. and Larsen, L. T. (2012). Morality Issues in Denmark: Policies Without Politics. In I. Engeli, C. Green-Pedersen and L. T. Larsen (Eds.), Morality Politics in Western Europe. Parties, Agendas and Policy Choices (pp. 137-160). Basingstoke: Palgrave Macmillan.

Albæk, E., Green-Pedersen, C. and Larsen, L. T. (2014). Moralpolitik i Danmark: Odense: The University of Southern Denmark Press.

Avisen (2010). K: Barnløshed er ingen sygdom, Avisen, May 26.

Banchoff, Thomas (2005). "Path Dependence and Value-Driven Issues: The Comparative Politics of Stem Cell Research", World Politics 57(2): 200-230.

Barad, K. (1998). Getting Real: Technoscientific Practices and the Materialization of Reality, Differences: A Journal of Feminist Cultural Studies 10: 87-128.

Berlingske (2011). Danmark ender som romerriget, Berlingske Tidende, December 1.

Bryld, M (2001). The Infertility Clinic and the Birth of the Lesbian. The Political Debate on Assisted Reproduction in Denmark, European Journal of Women's Studies 8(3): 299-312.

Castel, R. (1994). "Problematization" as a Mode of Reading History. In J. Goldstein (ed), Foucault and the writing of history (pp. 237-52). Cambridge: Blackwell.

Dahlgaard, M. (2013). Vil du være far til mit barn? Berlingske Tidende, July 13.

Dean, M. (1994). Critical and Effective Histories. Foucault's Methods and Historical Sociology. London: Routledge.

Dean, M. (1999). Governmentality. Power and Rule in Modern Society. London: Sage.

DR Nyheder (2006). Kunstig befrugtning til lesbiske og enlige. DR Nyheder, Jan- 
uary 26.

Engeli, I. (2012). "Policy Struggle on Reproduction: Doctors, Women, and Christians”, Political Research Quarterly 65(2): 330-45.

Engeli, I., C. Green-Pedersen and L. T. Larsen (Eds.) (2012). Morality Politics in Western Europe. Parties, Agendas and Policy Choices. Basingstoke: Palgrave Macmillan.

Ersbøll, E. (1996). Notat vedrørende Forslag til Lov om kunstig befrugtning i forbindelse med lægelig behandling, diagnostik og forskning m.v. (L200). Copenhagen: Det Danske Center for Menneskerettigheder.

Folketinget (1984a). Parliamentary Motion B116. Folketinget 1983-84, $1^{\text {st }}$ assembly. Copenhagen: Folketinget.

Folketinget (1984b). Parliamentary Motion B18. Folketinget 1983-84, $2^{\text {nd }}$ assembly. Copenhagen: Folketinget.

Folketinget (1997a). Health Committee Report on Law No. 5: "Lov om kunstig befrugtning i forbindelse med lægelig behandling, diagnostik og forskning m.v. Folketinget 1996-7. Copenhagen: Folketinget.

Folketinget (1997b). 2nd reading of Law No. 5: "Lov om kunstig befrugtning $i$ forbindelse med lægelig behandling, diagnostik og forskning m.v." Folketinget 1996-7. Copenhagen: Folketinget.

Folketinget (2010a). Introductory speech, Law No. 46: "Forslag til lov om ændring af lov om kunstig befrugtning i forbindelse med lægelig behandling, diagnostik og forskning m.v. samt sundhedsloven" (October 29, 2010). Copenhagen: Folketinget.

Folketinget (2010b). Parliamentary Committee Report on Law No. 46: "Forslag til lov om ændring af lov om kunstig befrugtning i forbindelse med lægelig behandling, diagnostik og forskning m.v. samt sundhedsloven" (December 8 2010). Copenhagen: Folketinget.

Folketinget (2010c). $1^{\text {st }}$ reading of Law No. 46: "Forslag til lov om ændring af lov om kunstig befrugtning i forbindelse med lægelig behandling, diagnostik og forskning m.v. samt sundhedsloven" (October 29, 2010). Copenhagen: Folketinget.

Folketinget (2015): "13 Political Parties", http://www.thedanishparliament.dk/About_the_Danish_Parliament/Political_partie s.aspx (URL accessed April 2015)

Foucault, M. (1976). La volonté de savoir. Histoire de la sexualité 1. Paris: Gallimard.

Foucault, M. (1984). Histoire de la sexualité 2: L'usage des plaisirs. Paris: Gallimard.

Foucault, M. (1990). Qu'est-ce que la critique? [critique et Aufklärung], Bulletin de la Société française de Philosophie, Compte rendu de la séance du 27 mai 1978.

Foucault, M. (1994a). La naissance de la médecine sociale, in Dits et Écrits III 1976-1979 (pp. 207-228). Paris: Gallimard. 
Foucault, M. (1994b). Le sujet et le pouvoir, in Dits et Écrits IV 1980-1988 (pp. 222-243). Paris: Gallimard.

Foucault, M. (1997a). 'Il faut défendre la société'. Cours au Collège de France 1975-6. Paris: Seuil/Gallimard.

Foucault, M. (1997b). Polemics, Politics, and Problematizations, in Essential Works of Foucault 1954-1984. Vol. 1: Ethics (pp. 111-119). London: Penguin.

Foucault, M. (2001). Nietzsche, la généalogie, l'histoire, in Dits et écrits I, 19541975 (pp. 1004-1024). Paris: Gallimard/Quarto.

Foucault, M. (2007). Security, Territory, Population. Lectures at the Collège de France 1977-1978. Basingstoke: Palgrave Macmillan.

Foucault, M. (2008a). The Birth of Biopolitics. Lectures at the Collège de France 1978-1979. Basingstoke: Palgrave Macmillan.

Foucault, M. (2008b). Le gouvernement de soi et des autres. Cours au Collège de France 1982-1983. Paris: Seuil/Gallimard.

Franklin, S. (2013). Biological Relatives. IVF, Stem Cells, and the Future of Kinship. Durham: Duke University Press.

Franklin, S. \& Roberts, C. (2006). Born and Made. An Ethnography of Preimplantation Genetic Diagnosis. Princeton: Princeton University Press.

Jackson, E. (2001). Regulating Reproduction. Law, Technology, and Autonomy. Oxford: Hart Publishing.

Hartlev, M. (2007). Med lov og etiske råd. Om legitimering af bioteknologien, in Kappel, K. and Lyngeskov, A. (eds), Etik i tiden - 20 år med det Etiske Råd 1987-2007 (pp. 167-184). Copenhagen: Etisk Råd.

Holberg, B. S. (2007). Sådan startede det, in Kappel, K. and Lyngeskov, A. (eds), Etik i tiden - 20 år med det Etiske Råd 1987-2007 (pp. 29-38). Copenhagen: Etisk Råd.

Indenrigsministeriet (1984). Fremskridtets pris. Copenhagen: Indenrigsministeriet.

Indenrigsministeriet (1987). Lov nr. 353 om oprettelse af et etisk råd og regulering af visse biomedicinske forsøg. Copenhagen: Indenrigsministeriet.

Indenrigsministeriet (1992). Lov nr. 503 af 24. juni 1992 om et videnskabsetisk komitésystem og behandling af biomedicinske forskningsprojekter. Copenhagen: Indenrigsministeriet.

Inhorn, M and Birenbaum-Carmeli, M. C. (2008). Assisted Reproductive Technologies and Culture Change, Annual Review of Anthropology 37: 177-96.

Johnson, M.H., Franklin, S.B., Cottingham, M. and Hopwood, N. (2010). Why the Medical Research Council refused Robert Edwards and Patrick Steptoe support for research on human conception in 1971, Human Reproduction 25(9): 21572174.

Justitsministeriet (1953). Betænkning om en særlig lovgivning om kunstig befrugtning. Copenhagen: Justitsministeriet. 
Kappel, K. and Lyngeskov, A. (eds), Etik i tiden - 20 år med det Etiske Råd 1987-2007. Copenhagen: Etisk Råd.

Koch, L. (2004). The Meaning of Eugenics: Reflections on the Government of Genetic Knowledge in the Past and the Present, Science in Context 17(3): 31531.

Koch, L. \& Hansen, A.K.K. (eds) (2008). Da reagensglasmetoden kom til Danmark 1977-1987: Rapport fra et vidneseminar. Copenhagen: Copenhagen University.

Larsen, E. (2007). Et tilbageblik på Det Etiske Råd og dets samspil med Christiansborg - set fra ministertaburetog udvalgsformandsstol, in Kappel, K. and Lyngeskov, A. (eds), Etik i tiden - 20 år med det Etiske Råd 1987-2007 (pp. 7186). Copenhagen: Etisk Råd.

Larsen, L.T. (2007). Speaking Truth to Biopower: On the Genealogy of Bioeconomy, Distinktion - Scandinavian Journal of Social Theory 14, 2007: 9-24.

Larsen, L.T. (2010) The Birth of Lifestyle Politics: The Biopolitical Management of Lifestyle Diseases in the United States and Denmark, in T. Lemke, S. Krasmann \& U. Bröckling (eds), Governmentality: Current Issues and Future Challenges. London: Routledge, pp. 201-220.

Larsen, L. T., D.T. Studlar \& C. Green-Pedersen (2012). Morality Politics in the United Kingdom: Trapped between Left and Right. In I. Engeli, C. GreenPedersen and L. T. Larsen (Eds.), Morality Politics in Western Europe. Parties, Agendas and Policy Choices (pp. 114-136). Basingstoke: Palgrave Macmillan.

Larsen, L.T. \& D. Stone (2015). Governing Health Care Through Free Choice: Neoliberal Reforms in Denmark and the U.S., Journal of Health Politics, Policy, and Law 40(5): 937-66.

Lemke, T. (2001). 'The birth of biopolitics': Michel Foucault's Lecture at the Collège de France on neo-liberal governmentality, Economy and Society 30: 190207.

Osborne, T. (2003). What is a problem? History of the Human Sciences 16(4): 117.

Petersen, M. N. (2009). Fra barnets tarv til ligestilling: En queerteoretisk undersøgelse af Folketingets forhandlinger om kunstig befrugtning, Kvinder, køn og forskning 2: 30-43.

Politiken (2012). 700 færre babyer efter at barnløse skulle betale selv, Politiken June 32012.

Rasmussen, S. (2012). Børn kommer fra stjernerne - med lidt hjælp fra storken. Jyllands-Posten, 26 May.

Regeringen (2010). Genopretningspakken. Danmark ud af krisen - regningen betalt. Copenhagen: Ministry of Finance.

Sørensen, L.M., Bannor-Kristensen, D. \& Hvidkjær, M. (2014): "Fertilitetslæger slår alarm: Barnløshed er blevet en folkesygdom”, dr.dk, Sept. 252014.

Thompson, C. (2002). Fertile Ground. Feminists Theorize Infertility, in Inhorn, M. 
C. and Balen, F. v. (eds) Infertility Around the Globe: New Thinking on Childlessness, Gender, and Reproductive Technologies (pp. 52-78). Berkeley: University of California Press.

Ziebe, S., Juul, A. \& Bay, K. (2013). Danskerne har ondt i forplantningen, Op-ed, Politiken, Feb. 122013.

Villadsen, J. (2002). Ingen børn til lesbiske. Information, April 6.

Walters, W. (2012). Governmentality. Critical Encounters. Abingdon: Routledge.

Øhrstrøm, Peter (2007). Værdidebatten om menneskelivets begyndelse, in Kappel, K. and Lyngeskov, A. (eds), Etik i tiden - 20 år med det Etiske Råd 19872007 (pp. 53-70). Copenhagen: Etisk Råd.

${ }^{1}$ Denmark has a unicameral parliamentary political system. Although there are many parties (8-13 in this period, i.e. since 1980), government power typically shifts between minority governments led either by the centre-left Social Democrats or by the major centre-right party (Liberals or Conservatives). As shown in the literature on morality politics (Engeli et al. 2012), issues like assisted reproduction deviate from the typical conflict structure in Danish politics, which is either a left-right conflict over economic policy or in recent years also a conflict over immigration policy. As a result, political parties dispense with otherwise strong party discipline and allow individual MPs to vote freely. Unlike other countries, courts have little significance on issues such as assisted reproduction and the Danish council of Ethics similarly has no decision-making powers. Because there are many parties with confusing and often counterintuitive names, I refer only by their official (and current) name in English. E.g. the party Venstre is termed the Liberal Party or Liberals, (Folketinget 2015), irrespective of whether their policy positions can be characterized as liberal ideologically. To simplify, I also use terms like 'the left wing' to characterize all centre-left and far-left parties together even though it varies whether individual parties define themselves in this conventional classification.

${ }^{2}$ The 1953 report did, however, formalize the expression 'artificial impregnation' (kunstig befrugtning) as the generic term for assisted reproduction used in Danish legislation until very recently. Being understood as artificial rather than simply as assisted underlines the general skepticism against the technique, i.e. as an unnatural and perhaps even unnecessary cover for something else.

${ }^{3}$ The only exception is the minuscule Christian Democrats (in Parliament 1973-94 and 1998-2005). Although unable to achieve any of its goals for restrictive legislation on abortion and embryo legislation, the Christian Democrats did persuade the health minister (Holberg, Liberal Party) to include this prolife preamble. The Minister allegedly expected the left wing parties to remove the preamble during parliamentary negotations (Øhrstrøm, 2007: 62-3; interview w. Margrete Auken). They did not and indirectly let the Council of Ethics be built on a prolife platform without revisiting their stand on abortion.

${ }^{4}$ Private and public funding for fertility treatment had of course been discussed before this point, but only after it was allowed for all groups has this become the main conflict. It is worth to add that a private market of fertility clinics existed alongside the public ones all along, because access to fertility treatment in the public system was always conditional upon age, existing children and number of failed attempts. 